\title{
Roadside Plants as Bio-indicators of Urban Air Pollution
}

\author{
A.P. Deepalakshmi ${ }^{1}$, H. Ramakrishnaiah ${ }^{1 *}$, Y.L. Ramachandra ${ }^{2}$, R.N. Radhika ${ }^{1}$ \\ ${ }^{I}$ Department of PG Studies and Research in Biotechnology, Government Science College,Bangalore- 560 001, \\ India. \\ ${ }^{2}$ Department of PG Studies and Research in Biotechnology and Bioinformatics, Kuvempu \\ University,Jnanasahyadri, Shankarghatta-577451, Karnataka, India.
}

\begin{abstract}
This paper describes air pollution tolerance among roadside plants exposed to varying degrees of vehicular pollutants. Evaluation of air pollution tolerance index (APTI) of 10 selected wild plant species was carried out to assess their response to ambient levels of air pollutants along the busy roadways of Bangalore. Four parameters namely total chlorophyll, ascorbic acid, $\mathrm{pH}$ of leaf extract and relative water content were determined and computed together to signify air pollution tolerance index (APTI) of plants. The observed significant reduction in total chlorophyll, ascorbic acid and relative water content showed inverse relationship with traffic density. Similarly, $p H$ of leaf extract followed an exponential decrease with increase in traffic density and drifted towards acidic range. Comparison of APTI values from control to polluted sites revealed maximum reduction in Bougainvillea spectabilis while least change was noted in Peltophorumpterocarpum. Among the plants studied maximum net per cent reduction of APTI over control was seen in Bougainvillea spectabilis and Ageratum conyzoides and are considered to be sensitive species. While Peltophorumpterocarpum and Portulacaoleraceaeare tolerant species since they have shown least per cent reduction in APTI.
\end{abstract}

Keywords: APTI, chlorophyll, ascorbic acid, relative water content, Bougainvillea spectabilis

\section{Introduction}

The atmosphere is a complex and dynamic gaseous system that is essential to support life on planet Earth. Rapid industrialization and urbanization coupled with increase in vehicular traffic in the urban areas has become a great threat to air quality, threatening the very existence of the living beings. Among the various categories, air pollution by automobiles is the most insidious one, which exerts highly detrimental effects on living organisms. Ambient air pollution in several large cities of India is amongst some of the highest in the world [1]. Bangalore too with its rapid growth and commercial activities harbours approximately 41.71 lakh vehicles releasing large quantities of pollutants such as oxides of nitrogen, sulphur, carbon, heavy metals, dust and particulate matter.

Among various strategies of controlling atmospheric pollution, absorption of gaseous pollutants by plants provide one of the natural ways of cleansing the atmosphere [2] and they act as effective indicators of air pollution [3]. Recent studies have explored the possibility to find out the ability of plants to remove and also act as sinks for air pollutants $[4,5]$.Biomonitoring is a low cost and valuable method to evaluate the effect of different air and environment pollutants [6]. There is hardly any data available on plants which act as sensitive, tolerant and resistant species to urban pollution, particularly vehicular pollution.

The air pollution tolerance index (APTI) based on four parameters, namely total chlorophyll, ascorbic acid, $\mathrm{pH}$ and relative water content have been used for identifying tolerance levels of these species [7, 8].APTI has been extensively used to rank plant species in their order of tolerance to air pollution [7,9]. In a similar attempt the present study was carried out to assess APTI of 10 angiospermic plants covering the busy roadways of Bangalore city.

\subsection{Study site}

\section{Materials and methods}

With a population of 8.5 million, Bangalore is the fifth largest city in India, positioned at $12^{\circ} 58^{\prime} \mathrm{N}$, $77^{\circ} 34^{\prime} \mathrm{E}, 12.97^{\circ} \mathrm{N}, 77.56^{\circ} \mathrm{E}$ and covers an area of $741 \mathrm{~km}^{2}$. Situated at 1000 meters above sea level, the city experiences salubrious savanna climate with distinct rainy, winter and summer seasons. Bangalore harbours 41.71 lakh vehicles, of which 28.81 lakh are two wheelers, 7.92 lakh cars, 1.62 lakh most polluting autos and 3.36 lakh other vehicles. The sites selected for the present study includes a control site (Kommasandra - S I), a moderately polluted residential site (Ramamurtynagar - S II) and a highly polluted site (Bangalore city railway station - S III) having an approximate traffic density of $<300,43,500$ and 73,800 vehicles respectively. 


\subsection{Plants}

The plant species selected for the present study are

Species

Family

Ageratum conyzoidesL.Asteraceae

BambusabambosL. VossPoaceae

Bougainvillea spectabilisComm. Ex. Juss.Nyctaginaceae

CynodondactylonL. Pers.Poaceae

FicusreligiosaL.Moraceae

MangiferaindicaL.Anacardiaceae

PeltophorumpterocarpumDC. K. HeyneFabaceae

PortulacaoleraceaeL.Portulacaeae

RicinuscommunisL.Euphorbiaceae

TerminaliacatappaL.Combretaceae

Fresh leaf samples of these plants were collected and analysed for the following parameters.

\subsection{Total chlorophyll}

The total chlorophyll was estimated principally by the method of Arnon [10]. One gram fresh leaf was macerated with $80 \%(\mathrm{v} / \mathrm{v})$ chilled acetone and a pinch of magnesium carbonate in a prechilled pestle and mortar. The extract was centrifuged at $2500 \mathrm{rpm}$ for 10 minutes. The process was repeated till the extract becomes colourless and the extracts were pooled and the volume was made up to $15 \mathrm{~mL}$. All operations were carried in the ice bath under dark condition. The absorbance was measured at 645, 663 and 750nm using UV-visible spectrophotometer.

$\mathrm{TCh}=20.2\left(\mathrm{~A}_{645}\right)+8.02\left(\mathrm{~A}_{663}\right) \times \mathrm{V} /(1000 \mathrm{x} \mathrm{W})$

Where,

$\mathrm{TCh}=$ Total chlorophyll in $\mathrm{mgg}^{-1}$

$\mathrm{A}_{645}=$ Absorbance at $645 \mathrm{~nm}$ minus the absorbance at $750 \mathrm{~nm}$

$\mathrm{A}_{663}=$ Absorbance at $663 \mathrm{~nm}$ minus the absorbance at $750 \mathrm{~nm}$

$\mathrm{V}=$ Total volume of the extract in $\mathrm{mL}$

$\mathrm{W}=$ Weight of the sample in $\mathrm{g}$

\subsection{Ascorbic acid}

One gram fresh leaf was homogenized in $4 \mathrm{~mL}$ of freshly prepared oxalic acid $(0.4 \% \mathrm{w} / \mathrm{v})$, filtered and centrifuged at $1000 \mathrm{rpm}$ for 20 minutes. Final volume was made up to $10 \mathrm{~mL}$ using oxalic acid. About $5 \mathrm{~mL}$ of the extract was titrated against standardized 2,6-dichlorophenol-indophenol [11].

$\mathrm{AA}=\mathrm{IxSxD} / \mathrm{Ax} 1 / \mathrm{W}$

Where,

$\mathrm{AA}=$ Ascorbic acid in $\mathrm{mgg}^{-1}$

$\mathrm{I}=\mathrm{mL}$ of indophenol used for titration

$\mathrm{S}=\mathrm{mg}$ of ascorbic acid reacting with $1 \mathrm{~mL}$ indophenol

$\mathrm{D}=$ total volume of the extract in $\mathrm{mL}$

$\mathrm{A}=$ Aliquot titrated in $\mathrm{mL}$

$\mathrm{W}=$ Weight of the sample in $\mathrm{g}$

\subsection{Relative Water Content}

The fresh weight of the leaves was determined and immersed in water over night. Turgid weights of the leaves were measured after blotting the leaves. The leaves were dried overnight in an oven at $80^{\circ} \mathrm{C}$ and the dry weight was determined [12].

$\mathrm{RWC}=(\mathrm{F}-\mathrm{D} / \mathrm{T}-\mathrm{D}) \times 100$

Where,

RWC $=$ Relative water content in \%

$\mathrm{F}=$ Fresh weight in $\mathrm{g}$

$\mathrm{T}=$ Turgid weight in $\mathrm{g}$

$\mathrm{D}=$ Dry weight in $\mathrm{g}$

\section{6. $\mathrm{pH}$ of the leaf samples}

Five grams of fresh leaves were homogenized in $10 \mathrm{~mL}$ deionised water. This was filtered and the $\mathrm{pH}$ of the leaf extract was determined after calibrating $\mathrm{pH}$ meter using buffer solution [12]. 


\subsection{APTI}

The air pollution tolerance indices were determined following the method of Singh and Rao [7].

$\mathrm{APTI}=\mathrm{AA}(\mathrm{TCh}+\mathrm{pH})+\mathrm{RWC} / 10$

Where,

APTI = Air pollution tolerance index

$\mathrm{AA}=$ ascorbic acid content in $\mathrm{mgg}^{-1}$

$\mathrm{TCh}=$ total chlorophyll in $\mathrm{mgg}^{-1}$

$\mathrm{pH}=\mathrm{pH}$ of leaf extract

$\mathrm{RWC}=$ relative water content in $\%$

\section{Results and Discussion}

The results of analysis of total chlorophyll and ascorbic acid are presented in table 1 and $\mathrm{pH}$ of leaf extract and relative water content table 2 .

\subsection{Total chlorophyll}

The concentration of total chlorophyll decreased in all the species growing at polluted sites when compared to the controls, with maximum reduction at S III which harbours highest vehicular density. Maximum total chlorophyll reduction was seen in Bougainvillea spectabilisand Portulacaoleraceae, moderate reduction in Peltophorumpterocarpum, Ricinuscommunis and Ficusreligiosa, while minimum reduction was observed in Mangiferaindica, BambusabambosandCynodondactylon. Since chlorophylls are the chief photosynthetic pigments, their content signifies growth and development of biomass and overall health status of plants. Decrease in chlorophyll content has been suggested as an indicator of $\mathrm{SO}_{2}$ pollution. High amount of gaseous $\mathrm{SO}_{2}$ causes destruction of chlorophyll and that might be due to the replacement of $\mathrm{Mg}^{++}$by two hydrogen atoms and degradation of chlorophyll molecules to phaeophytin [13]. A considerable loss of total chlorophyll in the plants exposed to pollutants supports the argument that the chloroplast is the primary site of attack by air pollutants such as $\mathrm{SPM}, \mathrm{SO}_{2}$ and $\mathrm{NO}_{\mathrm{x}}$ [5]. Pollutants such as $\mathrm{SO}_{2}, \mathrm{NO}_{2}$ and $\mathrm{O}_{3}$ cause damage to membranes and associated molecules including chlorophyll pigments [14].

Table 1:Mean concentration of total chlorophyll and ascorbic acidof selected plant species at different sites

\begin{tabular}{|l|c|c|c|c|c|c|}
\hline & \multicolumn{3}{|c|}{ Total chlorophyll $\left(\mathrm{mgg}^{-1}\right)$} & \multicolumn{3}{c|}{ Ascorbic acid $\left(\mathrm{mgg}^{-1}\right)$} \\
\hline \multicolumn{1}{|c|}{ Plants } & S I & S II & S III & S I & S II & S III \\
\hline A.conyzoides & $2.443 \pm 0.023$ & $1.823 \pm 0.260$ & $1.643 \pm 0.296$ & $0.263 \pm 0.291$ & $0.216 \pm 0.092$ & $0.142 \pm 0.208$ \\
\hline B.bambos & $1.991 \pm 0.156$ & $1.610 \pm 0.301$ & $1.382 \pm 0.316$ & $0.111 \pm 0.256$ & $0.098 \pm 0.276$ & $0.093 \pm 0.104$ \\
\hline B. spectabilis & $2.901 \pm 0.347$ & $1.899 \pm 0.098$ & $1.544 \pm 0.089$ & $0.433 \pm 0.333$ & $0.311 \pm 0.198$ & $0.081 \pm 0.273$ \\
\hline C.dactylon & $2.050 \pm 0.256$ & $1.523 \pm 0.125$ & $1.401 \pm 0.059$ & $0.158 \pm 0.089$ & $0.121 \pm 0.387$ & $0.101 \pm 0.124$ \\
\hline F.religiosa & $2.512 \pm 0.176$ & $1.645 \pm 0.287$ & $1.584 \pm 0.138$ & $0.150 \pm 0.302$ & $0.102 \pm 0.207$ & $0.083 \pm 0.242$ \\
\hline M.indica & $2.822 \pm 0.067$ & $2.237 \pm 0.311$ & $2.086 \pm 0.207$ & $0.210 \pm 0.099$ & $0.189 \pm 0.088$ & $0.159 \pm 0.255$ \\
\hline P.pterocarpum & $2.527 \pm 0.219$ & $1.664 \pm 0.200$ & $1.512 \pm 0.273$ & $0.222 \pm 0.103$ & $0.198 \pm 0.276$ & $0.142 \pm 0.087$ \\
\hline P.oleraceae & $2.926 \pm 0.311$ & $2.086 \pm 0.291$ & $1.635 \pm 0.345$ & $0.197 \pm 0.168$ & $0.148 \pm 0.157$ & $0.132 \pm 0.182$ \\
\hline R.communis & $2.323 \pm 0.249$ & $2.088 \pm 0.089$ & $1.403 \pm 0.301$ & $0.261 \pm 0.298$ & $0.255 \pm 0.298$ & $0.232 \pm 0.076$ \\
\hline T.catappa & $2.401 \pm 0.110$ & $1.895 \pm 0.196$ & $1.601 \pm 0.204$ & $0.116 \pm 0.345$ & $0.102 \pm 0.289$ & $0.093 \pm 0.156$ \\
\hline $\mathrm{n}=15$ & & & & & &
\end{tabular}

Table 2:Mean concentration of $\mathrm{pH}$ of leaf extracts and relative water content of selected plant species at different sites

\begin{tabular}{|l|c|c|c|c|c|c|}
\hline & \multicolumn{3}{|c|}{$\mathrm{pH}$} & \multicolumn{3}{c|}{ Relative water content (\%) } \\
\hline \multicolumn{1}{|c|}{ Plants } & S I & S II & S III & S I & S II & S III \\
\hline A. conyzoides & $6.71 \pm 0.302$ & $6.14 \pm 0.142$ & $5.43 \pm 0.086$ & $85.95 \pm 0.124$ & $71.72 \pm 0.134$ & $68.81 \pm 0.148$ \\
\hline B. bambos & $5.68 \pm 0.178$ & $5.24 \pm 0.257$ & $5.31 \pm 0.244$ & $45.37 \pm 0.323$ & $36.36 \pm 0.366$ & $34.21 \pm 0.198$ \\
\hline B. spectabilis & $5.76 \pm 0.079$ & $5.00 \pm 0.278$ & $4.74 \pm 0.194$ & $67.41 \pm 0.258$ & $53.10 \pm 0.234$ & $49.20 \pm 0.234$ \\
\hline C. dactylon & $6.71 \pm 0.355$ & $6.45 \pm 0.340$ & $6.26 \pm 0.350$ & $25.12 \pm 0.209$ & $21.40 \pm 0.098$ & $20.36 \pm 0.246$ \\
\hline F. religiosa & $7.59 \pm 0.198$ & $7.01 \pm 0.089$ & $6.43 \pm 0.254$ & $75.97 \pm 0.136$ & $61.10 \pm 0.124$ & $55.98 \pm 0.378$ \\
\hline M. indica & $6.93 \pm 0.154$ & $6.59 \pm 0.129$ & $6.02 \pm 0.187$ & $73.97 \pm 0.378$ & $61.71 \pm 0.186$ & $52.02 \pm 0.093$ \\
\hline P. pterocarpum & $7.01 \pm 0.257$ & $6.68 \pm 0.108$ & $6.01 \pm 0.108$ & $69.23 \pm 0.214$ & $62.14 \pm 0.099$ & $50.54 \pm 0.355$ \\
\hline$P$. oleraceae & $6.80 \pm 0.224$ & $6.62 \pm 0.386$ & $6.40 \pm 0.088$ & $76.23 \pm 0.125$ & $70.14 \pm 0.100$ & $64.26 \pm 0.236$ \\
\hline R. communis & $5.76 \pm 0.197$ & $5.70 \pm 0.134$ & $5.32 \pm 0.148$ & $88.4 \pm 0.263$ & $78.76 \pm 0.189$ & $70.16 \pm 0.248$ \\
\hline T. catappa & $5.50 \pm 0.173$ & $5.48 \pm 0.284$ & $5.39 \pm 0.247$ & $68.71 \pm 0.298$ & $58.21 \pm 0.294$ & $52.22 \pm 0.248$ \\
\hline
\end{tabular}$=15$
$\mathrm{n}$




\subsection{Ascorbic acid}

Traffic density dependent decrease in ascorbic acid content of all the species was noted. Maximum reduction in ascorbic acid content was recorded in Bougainvillea spectabilis, Ageratum conyzoidesand Ficusreligiosa, moderate reductionwas noted inCynodondactylon, Peltophorumpterocarpumand Portulacaoleraceae.While Ricinuscommunis, Bambusabambos, Terminaliacatappashowed least reduction. Reduction in ascorbic acid is attributed to increased rate of production of reactive oxygen species (ROS) during photo-oxidation of $\mathrm{SO}_{2}$ to $\mathrm{SO}_{3}[15]$. Ascorbic acid is an antisorbic vitamin, strong reducing agent reported to play an important role in $\mathrm{SO}_{2}$ reduction and it activates many physiological and defence mechanism, also maintains the stability of plant cell membranes during pollution stress. Its reducing power is directly proportional to its concentration [9].

\section{4. $\mathrm{pH}$}

All the plant samples collected from polluted site exhibited a shift in $\mathrm{pH}$ towards acidic range. High acidic $\mathrm{pH}$ was found in Bougainvillea spectabilis(4.74),Bambusabambos(5.31) and Ricinuscommunis(5.32). The presence of $\mathrm{SO}_{2}$ and NOx in the ambient air causes a change in $\mathrm{pH}$ of the leaf sap towards acidic range [17]. Upon diffusion of $\mathrm{SO}_{2}$ through stomata, gaseous $\mathrm{SO}_{2}$ dissolves in water to form sulphites, bisulphate and their ionic species with the generation of protons influencing the cellular $\mathrm{pH}$ [18]. It is therefore opined that the $\mathrm{pH}$ change towards acidic range observed in most species is due to entry of $\mathrm{SO}_{2}$ into leaf mesophyll tissue.

\subsection{Relative water content}

Plants growing in polluted site showed reduced relative water content, with maximum reduction in Mangiferaindica, Bougainvillea spectabilis, moderate reduction was observed in Peltophorumpterocarpum, Ficusreligiosa, Bambusabambosand minimum reduction in Portulacaoleraceaeand Cynodondactylon. Water content is an important factor which determines the physiological status of the plant. The relative water content is associated with protoplasmic permeability in cells.Loss of water and dissolved nutrients results in early senescence of leaves. The relative water content in a plant body helps in maintaining its physiological balance under stress conditions including air pollution stress [16]. The reduced relative water content indicates disturbed physiological status in the plants due to pollution [14].

\subsection{Air Pollution Tolerance Index}

The calculated APTI decreased progressively from control to highly polluted sites, table 3 .

Table 3:APTI and their per cent reduction over control (\%ROC)

\begin{tabular}{|l|c|c|c|c|}
\hline \multicolumn{1}{|c|}{ Plants } & S I & S II & \multicolumn{2}{c|}{ S III } \\
\hline & APTI & APTI & APTI & ROC \\
\hline Ageratum conyzoides & 9.15 & 6.48 & 5.12 & $44.06 \pm 0.251$ \\
\hline Bambusabambos & 4.62 & 3.70 & 3.48 & $24.64 \pm 0.109$ \\
\hline Bougainvillea spectabilis & 9.21 & 5.52 & 4.57 & $50.41 \pm 0.307$ \\
\hline Cynodondactylon & 2.65 & 2.33 & 2.27 & $14.22 \pm 0.298$ \\
\hline Ficusreligiosa & 7.74 & 6.19 & 5.66 & $26.87 \pm 0.273$ \\
\hline Mangiferaindica & 8.60 & 6.33 & 5.03 & $41.51 \pm 0.271$ \\
\hline Peltophorumpterocarpum & 7.13 & 6.67 & 6.36 & $10.84 \pm 0.346$ \\
\hline Portulacaoleraceae & 7.81 & 7.16 & 6.93 & $11.28 \pm 0.271$ \\
\hline Ricinuscommunis & 8.90 & 8.07 & 8.07 & $19.43 \pm 0.192$ \\
\hline Terminaliacatappa & 6.96 & 5.94 & 5.28 & $24.13 \pm 0.278$ \\
\hline
\end{tabular}
$\mathrm{n}=15$

The APTI of Bougainvillea spectabilis showed maximum decrease from S I (9.21) to S III (4.57), Cynodondactylonshowed least difference from control to polluted site with 2.65 to 2.27 respectively. The mean per cent reduction of APTI over control showed highest reduction in Bougainvillea spectabilis (50.41), Ageratum conyzoides(44.06)and Mangiferaindica(41.51), while least reduction was seen in Cynodondactylon (14.22), Portulacaoleraceae(11.28) andPeltophorumpterocarpum(10.84).

The results obtained for Cynodondactylonand Bougainvillea spectabilisare comparable to the results reported by Ramakrishnaiah and Somashekar [14]. The observed APTI values for Ficusreligiosa and Mangiferaindica closely agrees with Avnish [19]. The APTI results obtained for Bambusabambos (3.48 - 4.62$)$ and Terminaliacatappa (5.28 - 6.96) in the present study were lower when compared to that reported by Agbaire [20].

Many reports have indicated that the species with low index values are sensitive to air pollution and vice versa[21, 22, 23].The level of APTI exclusively depends on the intrinsic nature of each species since the level of total chlorophylls, ascorbic acid, $\mathrm{pH}$ and relative water contents varies greatly from species to species 
and they are not directly comparable. It is important to draw conclusions based on the differences in the amount of changes (\%ROC) observed within the species.

Due to their higher reduction in air pollution tolerance index over their control counterparts Bougainvillea spectabilisand Ageratum conyzoides are considered as more sensitive species, whereas Ficusreligiosa, Bambusabambosand Terminaliacatappawith moderate changesare regarded as tolerant species. While Peltophorumpterocarpumand Portulacaoleraceae with least APTI reduction over control counterparts are regarded as relatively resistant species. The plants of the former category can be effectively used as bioindicators of automobile exhaust pollution, whilst the resistant plants can be employed as sinks for vehicular pollutants.It is evident that the plants growing alongside busy roadways have exhibited significant reduction in total chlorophyll, ascorbic acid, relative water content and $\mathrm{pH}$ of leaf extracts and has resulted in the substantial reduction of air pollution tolerance in plants. This is because of the pollutants released by automobiles.

\section{Conclusion}

Air pollution has been considered as a potential selection force for plants, therefore the species growing in such adverse roadside environment present the best material to ascertain the levels of susceptibility rather than drawing interpretations from measurements obtained from lab conditions. Furthermore, APTI determination provides a reliable method for screening large number of plants with respect to their response to air pollutants.

\section{References}

[1] M. Agrawal, Effects of air pollution on agriculture: An issue of national concern, National Academy Science Letter, 28, 2005, 93106.

[2] S.R.K. Varshney, and C.K. Varshney, Response of peroxidase to low levels of $\mathrm{SO}_{2}$, Environmental and Experimental Botany, 25, $1985,107-114$.

[3] A. Rai, K. Kulshreshtha, P.K. Srivastava, and C.S. Mohanty, Leaf surface structure alterations due to particulate pollution in some common plants, Environmentalist, 30, 2009, 18-23.

[4] A.K. Dwivedi, and B.D. Tripathi, Pollution tolerance and distribution pattern of plants in surrounding area of coal-fired industries, Journal of Environmental Biology, 28(2), 2007, 257-263.

[5] A.K. Tripathi, and M. Gautam, Biochemical parameters of plant as indicators of air pollution, Journal of Environmental Biology, 28(1), 2007, 127-132.

[6] S.R. Oliva, B.V. Castrillon, M. Dolores, and M. Alvarez, Nerium oleander as a means to monitor and minimize the effects of pollution, Bocconea, 21, 2007, 379-384.

[7] S.K. Singh, and D.N. Rao, Evaluation of the plants for their tolerance to air pollution, Proceedings symposium on air pollution control held at IIT, Delhi, 1983, 218-224.

[8] S.K. Singh, D.N. Rao, M. Agrawal, J. Pandey, and Narayan, Air pollution tolerance index of plants, Journal of Environmental Management, 32, 1991, 45-55.

[9] S.H. Raza, and M.S.R. Murthy,Air pollution tolerance index of certain plants of Nacharam industrial area, Hyderabed, Indian Journal of Botany, 11(1), 1988, 91-95.

[10] D.I. Arnon, Copper enzyme in isolated chloroplasts, polyphenoloxidase in Beta vulgaris, Plant Physiology, 24, 1949, 1-15.

[11] B. Aberg, Ascorbic acid, in W.Ruhland (Ed.), Encyclopedia of Plant Physiology, 6, (New York: Springer-Berlin-Heidelberg,1958) 479-499.

[12] A. Singh, Practical plant Physiology (New Delhi: Kalyani Publishers, 1977).

[13] F. LeBlanc, and D.N. Rao, Reaction of several lichens and Epiphytic mosses to sulfur dioxide in Sudbury, Ontario, Bryologist, 69, 1966, 338-346.

[14] H. Ramakrishnaiah, and R.K. Somashekar, Higher plants as biomonitors of automobile pollution, Ecology, Environment and Conservation, 9(3), 2003, 337-343.

[15] J.S. Jyothi, and Jaya, Evaluation of air pollution tolerance index of selected plant species along roadsides in Thiruvananthapuram, Kerala, Journal of Environmental Biology, 31, 2010, 379-386.

[16] W. Dedio, Water Relations in wheat leaves as screening test for drought resistance, Canadian journal of Plant Sciences, 55, 1975, 369-378.

[17] A. Swami, D. Bhatt, and P.C. Joshi, Effects of automobile pollution on sal (Shorearobusta) and rohini (Mallotusphillipinensis) at Asarori, Dehradun, Himalayan Journal of Environment and Zoology, 18(1), 2004, 57-61.

[18] S.S. Malhotra, and A.A. Khan, Biochemical and biophysical impact of major pollutants, in Treshow M. (Ed.) Air pollution and plant life (New York: John Wiley and Sons, 1984) 113-157.

[19] AvnishChauhan, Tree as bio-indicator of automobile pollution in Dehradun city: a case study, New York science journal, 3(6), 2010, 88-95.

[20] P.O. Agbaire, Air pollution tolerance indices (APTI) of some plants around Erhoike-Kokori oil exploration site of Delta State, Nigeria, International Journal of Physical Sciences, 4(6), 2009, 366-368.

[21] P. Suvarna Lakshmi, K. LalithaSravanti, and N. Srinivas, Air pollution tolerance index of various plant species growing in industrial area, The Ecoscan, 2(2), 2008, 203-206.

[22] Abida Begum, and S. Harikrishna, Evaluation of some tree species to absorb air pollutants in three industrial locations of south Bengaluru, India, E-journal of chemistry, 7(S1), 2010, 151-156.

[23] D. SaralaThambavani, and M.A. Sabitha, Variation in air pollution tolerance index and anticipated performance index of plants near a sugar factory: implications for landscape-plant species selection for industrial areas,Journal of research in biology,1(7), 2011, 494502. 